\title{
Den dialogiske stemme og den dialogiske krop
}

I en nyligt publiceret artikel har Ladislav Matejka uddybet sit forsvar for, at Volosjinov og Medvedev er de egentlige forfattere til de bøger, som blev udgivet i deres navne. Den hypotetiske og ofte fjendtlige debat blev sat i gang af V.V. Ivanov, som i 1970 hævdede, at Bachtin i virkeligheden var forfatteren til Marxism and the Philosophy of Language og Freudianism. A Marxist Critique (begge udgivet i Volosjinovs navn) og The Formal Method in Literary Scholarship (udgivet i Medvedevs navn). Denne påstand er nu stille forduftet, selvom den blev bekræftet af mange af de mest indflydelsesrige fortalere for og fortolkere af Bachtin i den engelsktalende del af verden, ikke mindst Clark \& Holquist og Emerson \& Morson. Gennem 1980'erne var Matejka og Titunik næsten alene om at forsvare ejendomsretten for de to temmelig ukendte forskere, som efter Matejkas og Tituniks mening var ofre for et tekstligt og intellektuelt tyveri. I 1988 fandt Sergei Averintcev beviset og argumentationen så forvirrende, at han foreslog »uden forlegenhed at lade problemet være uløst og betragte det som uløseligt.« Dette er et citat fra Sergei Bocharov, som i et essay fra 1993 leverer yderligere bevis med erindringerne fra sin »Conversations with Bakhtin « - og disse bevisdele er også modsigelsesfulde. ${ }^{1}$

Uanset om man kan enes om, at forfatterskabsspørgsmålet skal forblive uløst eller ej, så er drivkraften i kontroversen forsvundet. Ladislav Matejka har nu drejet polemikken fra Bachtins udgiveres, venners, disciples, biografers og kommentatorers tvivlsomme praksis til Bachtins egen. Den første kontrovers fortæller os noget om vanskelighederne med receptionen af en russisk tænker under den kolde krig: Når - hvis nogensinde - hele historien bliver fortalt, vil den i det mindste være emblematisk for det intellektuelle livs kappestrid, der er så udpræget i vores æra.

I en tone, der er næsten lige så ondskabsfuld som tonen i I. Tituniks »Bakhtin \&/or Volosinov \&/or Medvedev «, ${ }^{2}$ fortsætter Matejka polemikken i »Deconstructing Bakhtin. $\ll^{3}$ Flere passager i en af Bachtins første, vægtige tekster, »The Problem of Content, Material and Form in Verbal Art«, er identificeret som oversættelser eller parafraseringer af Broder Christiansens Philosophie 
der Kunst, der blev oversat til russisk i 1911. Matejka påpeger, at det var den russiske oversættelse af Christiansens bog, der gav de russiske formalister nogle af deres vigtigste termer, så som 'differensoplevelser', 'dominanten' og 'forgrundende'. ${ }^{4}$ Sådanne genealogiske klarlæggelser er gavnlige uanset deres motivation. Men det er selvsagt de, der har en interesse i at formindske Bachtins prestige, der vil søge mest ihærdigt efter vidnesbyrd om hans lån, hans gæld, hans 'plagiering'.

Disse undersøgelser kan hjælpe os med at forklare nogle af skiftene og udviklingerne i Bachtins tænkning, således som vi forstår den fra de tekster, der er udgivet i Bachtins navn, og som ingen har fors $\varnothing g t$ at tilskrive en anden forfatter. Den store forandring opstår mellem de tidligst overlevende tekster, »Author and Hero in Aesthetic Activity (1920-23) og »The Problem of Content, Material and Form in Verbal Art « (1924), og bogen om Dostojevskij fra 1929. Matejka har ret $\mathrm{i}$ at henlede opmærksomheden på den radikale forskel mellem disse tidlige værker og de værker fra slutningen af 1920'erne, som tilskrives Bachtin. Man er mere forundret over dem, der bruger Bachtins værker fra begyndelsen af 1920'erne som nøglen til hans tænkning - værker der slet og ret ikke blev udgivet, mens han levede. Blandt dem, som følger denne linje, er Clark \& Holquist, der ser konceptet om 'ansvarlighed' blive udfoldet gennem hele Bachtins karriere. I 1990 samlede Holquist og Liapunov de to lange essays fra de tidlige 1920 'er sammen med et meget kort og dagsaktuelt bidrag til en avis i 1919, og de opkaldte hele bindet Art and Answerability efter titlen på denne korte og ubetydelige tekst. I sin beskrivelse af den første udgivelse af Bachtins tidligste skrifter i 1970'erne, forklarer Liapunov, hvorledes Bachtins tilhængere udgav Voprosy literatury i estetiki [Spфrgsmål om litteratur og cestetik] i 1975, året for Bachtins død, og den »indeholder den fundamentale artikel fra $1924 »$ The Problem of Content, Material and Form in Verbal Art «.$^{5}$ Det er svært at indse, hvad der er fundamentalt ved denne artikel, især når Holquist og Liapunov lader Early Philosophical Essays være undertitlen på Art and Answerability. Den er en tosiders skitse, et kauseri, som bekræftende konkluderer: »Kunsten og livet er ikke ét, men skal i mig blive forenet, skal forbindes i min ansvarlighed.« Dette kan være tidligt, men det er ikke filosofisk, ikke en gang et essay. »Author and Hero « optager 250 sider af bindet og det er helt sikkert filosofisk, men lige så sikkert ikke et essay. Og som det mest forbløffende er »The Problem of Content, Material and Form « udgivet som et »Supplement« til bindet. Det er faktisk det mest filosofiske og mest essayistiske af de tre tekster i dette bind.

Der er her megen usikkerhed af en foruroligende art. For hvis man antager, at disse tidlige tekster er 'fundamentale' for udviklingen i Bachtins tænkning, af hvilke grunde ville man da ønske at tilskrive Bachtin Volosjinovs og Med- 
vedevs værker. Som Titunik og Matejka klart har vist, er tonen og den ideologiske position i hver af disse tekster tydelig og distinkt. Volosjinov og Medvedev er udtalte marxister i deres sprogbrug; mens Bachtins tekster lige så åbenbart kæmper med nykantianismen og en ikke-marxistisk vej væk fra denne særlige skole. For dem, der følger linjen med Clark \& Holquist, Holquist \& Liapunov, Holquist, Emerson \& Morson, er ansvarlighed en vedvarende værdi, en prøvesten i Bachtins diskurs. Den mest slående konsekvens er, at det dialogiske bliver sat i forgrunden og det karnevaleske undertrykt. Holquists korte introduktion til Bachtin hedder simpelthen Dialogism ${ }^{6}$ og Rabelais er knap nok nævnt. Morson \& Emersons omfangsrige bog, Mikhail Bakhtin. Creation of a Prosaics (1990), er veltalende om emnet 'det dialogiske', især om ansvarligheden, men nærmest tavs om det karnevaleske. Den forsøger et sted at forløse det besværlige koncept ved at påkalde sig »det vi kunne kalde et 'ansvarligt karneval' « - et karneval, formoder vi, for puritanerne. ${ }^{7}$ Året efter lykkedes det for en bog, The Thought of Mikhail Bakhtin, helt at undgå ordet og konceptet om karneval. ${ }^{8}$

Hvis vi skal forstå det fænomen, som Bachtinreceptionen udgør, skal vi huske, at det første af Bachtins værker, som blev oversat til engelsk i 1968, var Rabelais and His World. Udgiverne af »New York Review of Books « fornemmede dets vigtighed og anmodede om en anmeldelse fra en af vort århundredes største forskere i renæssancens tænkning: Frances Yates. I den engelsktalende del af verden blev Bachtin først betragtet som en specialist i renæssancens kultur, omend lidt uden for forskrifterne. Hans videnskabelighed var noget mangelfuld og hans tendentiøsitet var lige så synlig som hans fodnoter var usynlige. ${ }^{9}$ Tendensiøsiteten blev antaget for at være af marxistisk karakter, og i Frankrig i de sene 1960'er blev Bachtin med en næsten desperat entusiasme hilst velkommen som den eneste marxistiske tænker, der var dukket frem fra Sovjetunionen.

Det arbejde, som blev udført af dem, der har promoveret og forsvaret Bachtin gennem de sidste tyve år, må forstås på denne baggrund. De første misforståelser måtte korrigeres. Bachtin var ikke marxist. Han var heller ikke Rabelaisforsker i konventionel forstand; faktisk - for at bruge den samme retorik som de tendentiøse - var Bachtin humanist, moralist, individualist, helt klart på vores side af jerntæppet. Således blev bogen om Rabelais skubbet til side til fordel for det langt mere, i normal litteraturvidenskabelig forstand, overlegne værk Problems of Dostojevsky's Poetics (1984) og de udvalgte essays i The Dialogic Imagination (1981). Vi bør pointere, at Holquist, Emerson og Liapunov alle har været omhyggelige og trofaste i deres rolle som oversættere. Dog var bogen om Rabelais oversat uden nogen form for kommentarer eller tekstapparat, og der har ikke været noget pres overhovedet for at lave en ny 
oversættelse eller i det mindste en modificeret oversættelse med assistance fra Emerson.

Effekten har været at holde Bachtin nede i 1920'erne og de tidlige 1930'er; vægten har ligget på hans tidligste skrifter. Dog er det stadigvæk ikke klart, hvorfor det er nødvendigt at tilskrive Bachtin nogle yderligere værker med en eksplicit marxistisk retorik, hvis man ønsker at gøre Bachtin gangbar i Vesten. Selvfølgelig har det været nemt at argumentere for, at Bachtin brugte marxistisk terminologi for at snyde censuren. I den forstand har de, som argumenterer for Bachtins 'udvidede forfatterskab', ikke været nødt til at beskæftige sig med de seriøse problemer omkring modsætningsfulde stillejer og argumenter. Dette problem har det været overladt til Titunik og Matejka at forklare.

Clark og Holquist hævdede også, at Bachtin var forfatteren til essayet »Contemporary Vitalism«, der blev skrevet af KanaÎv. Dette essay blev dog ikke oversat til engelsk i noget bind, før det uvarslet, næsten skjult, fremkom i en essaysamling om Henri Bergson - The Crisis in Modernism. Bergson and the Vitalist Controversy. ${ }^{10}$ Essayets overskrift er $»$ Contemporary Vitalism Mikhail Bakhtin«, og oversætterens note lyder: »Den følgende artikel udkom i to dele i 1926 i tidsskriftet 'Chelovek i Priroda' (Mennesket og naturen), vol. 1 og 2, under I. KanaÎvs navn, men det er blevet erkendt, at det alene er Michail Bachtins arbejde, eftersom Kanâ̂v anerkender Bachtin som forfatteren. ${ }^{11}$ Her udvises end ikke den anstændighed, som altid er blevet vist over for Volosjinov og Medvedev, at sætte en bindestreg eller lave en anden antydningsvis indikation af et fælles eller et ubestemmeligt forfatterskab. Da Holquist synes at give sin autoritet til denne oversættelse af »Contemporary Vitalism«, kunne man godt lide at vide, hvorfor dette essay ikke var med mellem Early Philosophical Essays i bindet Art and Answerability, hvis det fuldt ud er et af Bachtins arbejder.

Denne form for videnskabelig uansvarlighed (for Holquist er intetsteds nævnt som 'ansvarlig' for denne specifikke oversættelse og dette intellektuelle tyveri) fortsætter med at forvirre debatten. Særdeles unyttig er det lancerede indtryk, at Bachtin var involveret i nogle ret gammeldags debatter med Bergson og Driesch i »Contemporary Vitalism« og med Herman Cohen og Paul Natrop og Marburg nykantianismen i de tidlige essays.

Dog er, som Matejka har argumenteret for, en af de mest åbenbare forskelle mellem de skrifter, der står i Bachtins navn, og dem som står i andres navne, at Volosjinov og Medvedev altid angiver deres kilder, og at Bachtin er ekstremt tilbageholdende med det. Eksempelvis noterer Matejka, at Volosjinov i Marxism and the Philosophy of Language anvender begrebet 'nesobstvenno prjamaja rec' med fuld anerkendelse af, at det er Gertraud Lerchs begreb 'Die uneigentliche direkte Rede'. Matejka fortsætter: 
»Forunderligt nok brugte Bachtin ikke Lerchs/Volosjinovs begreb i sin bog om Dostojevskij..., udgivet i 1928, det samme år som Volosjinovs Marxism and the Philosophy of Language oprindelig blev udgivet, selv om begge bøger diskuterer rapporteret tale (cuzaja rec) ... Volosjinovs oversættelse og lån af Gertraud Lerchs begreb blev først brugt af Bachtin i »Slovo v romane« [Ordet i romanen], som påstås at være blevet skrevet i 1934-5, men først udgivet i $1975 . \ll^{12}$

Matejka argumenterer for, at Bachtin var meget påvirket af Karl Vossler og hans tilhængere, heriblandt Lerch. Han hævder også, at Bachtin i vid udstrækning anvendte Leo Spitzers Italienische Umgangssprache (1919), hvilket Bachtin selv anerkender i bogen om Dostojevskij (én gang, hvor han citerer Spitzer på side 194).

Man kunne argumentere for, at Bachtin netop undgår Gertraud Lerchs begreber, fordi han ikke ønsker, at hans projekt omkring det dialogiske skal blive sammenblandet med den lingvistiske undersøgelse af dækket direkte tale. Bachtin er ikke interesseret i rapporteret tale som lingvistisk fænomen - som det findes hos nogle romanforfattere - men i dets implikationer for romanens diskurs generelt.

Det dialogiske har, ifølge Bachtin, intet at gøre med tale. Det er bestemt af repræsentationen af stemmer på skrift i romanens diskurs. Dækket direkte tale, eller 'ubestemt direkte tale' (som Lerch skriver) sætter et problem: Hvem tilhører disse ord? Bachtin modtager og reviderer problemet som en mulighed: At ord, tale i fiktionens utopiske rum kunne være uden ejere, subjektløse stemmer: Disse ord tilhører ikke nogen, ikke nogen krop. Bachtin hentyder ikke til Lerch eller Vossler end ikke til Volosjinov, fordi han ikke ønsker, at det dialogiske skal behandles som en variation, en modifikation af dækket direkte tale.

Takket være Matejkas detektivarbejde, hvor hævngerrig dets motivation end er, kan man her opspore forbindelsen mellem det dialogiske i stemmen og det dialogiske i kroppen, dét der af Bachtin kaldes det karnevaleske. Den store opmærksomhed, der er blevet helliget Bachtins arbejde fra midten af 1920'erne, den megen omsorg for at sammenkæde, sammenbinde den senere Bachtin med hans nykantianske dannelse, har stort set tilsløret vigtigheden af det karnevaleske. Der synes ikke at være nogen som helst interesse for den bevægelse, Bachtin foretager fra det dialogiske til det karnevaleske, fra Dostojevskij til Rabelais gennem de essays, der findes i The Dialogic Imagination. En bevægelse, der indeholder genskrivningen af bogen om Dostojevskij, så den får et helt kapitel om karnevallet, og indeholder en genskrivning af kro- 
notopessayet, så det får en uforholdsmæssig lang del om Rabelais. Disse bevægelser er vanskelige at spore, og Morson \& Emerson har advaret:

»Derfor må vi i læsningen af det nye kapitel 4 [i Dostojevskijbogen] spørge os selv, hvor organisk dets diskussion af karneval og menippæisk satire forbinder sig med strukturen og logikken i bogen som helhed. Karnevalsekskursen [!] er flankeret af kapitel 3, »The Idea in Dostojevky«, og kapitel 5, »Discourse in Dostojevsky«, hvis indhold grundlæggende er uforandret siden $1929 . \ll^{13}$

'Karnevalsekskursen' er en måde at redde Dostojevskij fra karnevallet, og ved at identificere Bachtin så tæt med bogen om Dostojevskij fra 1929 lykkedes det Morson og Emerson at redde Bachtin selv fra karnevallet.

Matejka trækker den samme pointe frem angående den skødesløse læsning af Bachtins Dostojevskij, som undlader at sammenligne versionerne fra 1963 og 1929. ${ }^{14}$ Imidlertid angår Matejkas mere produktive observationer Leo Spitzer - der som Lerch studerede hos Karl Vossler - og det bredere problem, at Baktin udgav så få tekster på det tidspunkt, hvor de (med Matejkas ord) 'påstås' at være blevet skrevet:

»Men det var ikke kun Spitzers bog fra 1919, som havde en afgørende indflydelse på Bachtins tænkning. Vi må formode, at Bachtin var vidende om andre af Spitzers skrifter, selvom han undlod at citere ham. Han kendte helt sikkert Spitzers studier om middelalderlig latter, om karneval og specifikt om Rabelais, som var emnet for Spitzers doktorafhandling i 1910, og som fortsatte med at tiltrække Spitzer gennem hele hans karriere, ikke kun i Tyskland, men også ved Johns Hopkins Universitet i Baltimore. Det er sandsynligt, at Spitzers beslutning om at emigrere fra Nazi-Tyskland til USA og blive amerikansk statsborger var hovedårsagen til, at Bachtin ikke turde henvise til ham så ofte som Spitzer fortjente. For den sags skyld ignorerede Bachtin også konsekvent Roman Jakobsons studier i poetik og litteraturteori [en russisk emigrant kunne ikke blive citeret i sovjetisk videnskab], herunder »Medieval Mock Mystery«, hans bemærkelsesværdige bidrag til Spitzer-festskriftet i 1958, hvor Jakobson diskuterer middelalderlig latter, Kristi fødsel og genopstandelse som narrespil. I virkeligheden er parallellerne mellem Spitzers og Jakobsons bemærkninger om middelalderlig latter og Bachtins observationer om middelalderlig latter i hans bog om Rabelais (1965) ganske slående. Vi ved selvfølgelig ikke, om Bachtin havde adgang til Spitzer-fest- 
skriftet. Men vi ved, at Bachtins Rabelais først blev udgivet i 1965, syv år efter Spitzer-festskriftet $\ll .{ }^{15}$

I en så omfattende anklage kunne Matejka også have nævnt Curtius’ Europäische Literatur und Lateinisches Mittelalter (1949) med dens ekskurs til »Spøg og alvor i middelalderlig litteratur« eller Wolfgang Kaysers værk om karneval. Vi kunne også nævne Lucien Febvres Le problème de l'incroyance au XVIe siècle. La religion de Rabelais, der blev udgivet i 1942. Jeg har ingen interesse $\mathrm{i}$ anklagerne for plagiering, og jeg reserverer min irritation til Bachtins tilhængere og udgivere. Imidlertid ønsker jeg at signalere en taknemmelighed over for Matejka og Titunik for afdækningen, eller som de nok ville sige, 'afsløringen' af nogle af Bachtins kilder.

Interessen for karnevallet, for forskellige former for humor, parodi og blasfemi, fremstår som noget af en gåde inden for moderne litteratur- og kulturvidenskab. Da blasfemi syntes at være blevet et objekt for antikvarisk undersøgelse i en fuldt ud sekulariseret og affortryllet verden, vendte det tilbage som et centralt begreb for en række 'progressive' tænkere og videnskabsmænd. Og disse videnskabsmænd var ikke historikere eller antropologer, men lingvister, filologer, stilistikere: Det kompleks af kompetencer, som er mest beundringsværdigt til stede i Spitzers, Curtius', Auerbachs og Bachtins arbejder.

Jeg vender nu tilbage til det dialogiske, diskursen uden en enkelt stemme, eller det polyfone, som ikke betyder det samme som den musikalske term, dvs. sammensmeltningen af mange stemmer i en lyd eller spillet mellem de mange og den enkelte. For Bachtin betyder 'polyfon' de mange stemmer, der kan blive hørt i ethvert ord. Igen må man understrege, at Bachtin altid skriver om romanens diskurs, ikke om talende stemmer, men om stemmer repræsenteret i prosa. At forstå det dialogiske som stemmer i dialog er at reducere Bachtin til vulgær liberalisme og at kanonisere individets ansvarlighed. Det er af denne grund kommentatorerne opsporer og insisterer på sammenkædningen af de tidlige filosofiske skrifter og bogen om Dostojevskij.

Når vi taler, når jeg taler - for i talen er enhver ytring ikke 'fri' eller 'uneigentlich', men bundet til en enkelt stemme - er jeg ansvarlig for, hvad jeg siger. Det forunderlige ved romanen - hvilket forbinder sig med dens særlige historiske opkomst sammen med de demokratiske repræsentationsformer - er, at de rapporterede former for sådanne individualiserede ytringer ikke længere er klart individualiseret. (Vi taler selvsagt ikke om 'ren' repræsentation, som om liv, virkelighed, samfund, politik var autonome områder; litteratur er bestemmende for vores forståelse: Romanen gør demokrati mulig i en nærmest banal forstand.) Ordet undslipper ejerskab. Romanen leverer det diskursive 
rum, hvorindenfor sproget kan frigøre sig selv fra kapitalismens normer og regler. Romanen er således et idealt rum, et utopisk rum, en horisont for revolutionære bestræbelser.

'Ansvarlige' og etiske kritikere er bekymret for verdens moralske tilstand, når det er en verden, hvor ordene er uden ejere. Hvad sker der efter revolutionen? Hvor er beskyttelsen? Som enhver anden god utopisk tænker lader Bachtin sig ikke gå på af sådanne spørgsmål. Med undtagelse af at sige - og det er det afgørende - at hvor der ikke er nogen ejendomsret til ordene, kan der ikke være noget monologisk ord, ingen autoritativ tale. Dette er netop den etiske frygt: Hvor vil autoriteten befinde sig? Hvem skal vi tro på? Som han skriver $i$ »Notes Towards a reworking of the Dostojevsky Book«: »Endegyldig betydning er begrænset betydning. $\aleph^{16} \mathrm{I}$ denne verden lever vi i en provisorisk tilstand, en tilstand hvor vi konstant er på udkig efter endegyldig betydning. Den 'endegyldige betydning' af ord finder vi i forfatterens stemme og bevidsthed, intentionen. Romanen, præcist den dækkede direkte tale, gør denne bevægelse umulig. Den undviger den dialektik, med hvilken vi hvert øjeblik lever for forberedelsen af den endegyldige betydning. Det dialogiske signalerer alternativet til dialektikkens terror - en tænkemåde som nyder et reelt monopol fra Platon til Hegel, og som er afsløret som terrorinstrument i det stalinistiske Rusland og i Hitlers Tyskland. Intet mindre end det er summen af anklagerne i Adorno \& Horkheimers Oplysningens dialektik (1947).

Det dialogiske bliver ikke afløst af det karnevaleske, og der er heller ikke en sti, som leder fra den ene til den anden. Der er blot et skridt, et metonymisk skridt fra tænkningen over ordene frigjort fra stemmerne, eller beboet af mange stemmer, til drømmen om kroppe frigjort fra besiddere. Jeg takker Matejka for at påpege, hvorledes dette skridt allerede var blevet taget, trods den distancerede og videnskabelige måde, af Spitzer og andre i Vossler-traditionen. At tænke seriøst på ikke-ejet tale, er uundgåeligt at tænke på andre utænkeligheder, såsom de ikke-ejede kroppe. For den tale, der kommer som stemme fra kroppen, kan kun være i ejerløs tilstand på papiret, i skriften. Det dialogiske er et strengt tekstligt fænomen.

Friheden er opnået gennem det Bachtin kalder vnenakhodimost, 'udenforståenhed'.$^{17}$ Inderlighed, det indforståedes figur, er det som gør 'afsluttelighed' mulig: at kende det indre er at sætte grænser for det ydre. Og det er Rabelais som foretager »det højst bemærkelsesværdige eksperiment at genskabe det fuldt ud yderliggjorte individ i verdenslitteraturen $\kappa^{18}$

»Vi skal fremhæve det faktum, at hos Rabelais har livet absolut ingen individuelle aspekter. Et menneske er fuldstændig ydre. De kendte grænser for menneskets mulige yderliggjorthed er opnået.... der er ikke et 
eneste tilfælde i den fulde udstrækning af Rabelais' store roman, hvor vi får vist, hvad en karakter tænker, hvad han oplever, hans indre dialog ... der er i Rabelais' roman ingen indre verden. ${ }^{19}$

Bachtin er tilbageholdende med sine kildeangivelser; han er en alluderende forsker. Når han taler om Rabelais' 'genskabelse' af yderliggjorte karakterer, må vi høre allusionen til Lessing og Schiller, til den rene yderliggjorthed hos den homeriske helt og til den tyske romantiks fascination heraf såvel som til den for altid tabte uskyld, der fulgte med udviklingen af det sentimentale.

Kroppen hos Rabelais er ren ydre og derfor uden privathed. Det karnevaleske hylder kroppens åbninger, ikke fordi de er obskøne, men fordi de er passager. Snarere er de obskøne, fordi det er i sådanne passager, at privat ejendom kan forandres til affald. Det som er affald for kroppen, er simpelthen det som ikke er privat. I det karnevalistiske er der ingen skel mellem det private og det offentlige, det ejede og det ikke-ejede (vi vil ikke eje det som er skamfuldt), det indre og det ydre: kroppen nyder (men hvem nyder nydelsen?) den samme frihed, som ordene nyder i deres dialogiske rum.

Det sentimentale afslutter, sætter en grænse for udtryk og fremtræden. Det næste problem er at finde ud af, hvorledes Bachtin på den ene side kan hylde romanens opståen af eposet, hvordan han kan ære romanen som den mest befriende af de litterære og lingvistiske former, og netop gøre det udtrykt i romanens repræsentation af indre stemmer; og på den anden side, hvorledes han kan hylde Rabelais for genskabelsen af eposets yderliggjorthed. (Jagten på konsistens, som på kilder, er selvfølgelig en dialektikkens tvang.)

\section{Oversat af Jan Lundquist}

\section{Noter}

1. Sergei Bocharov: »[About One Conversation and its Context] «, in [New Literary Review], 2, 1993, pp. 70-89; oversat og forkortet af Stephen Blackwell og Vadim Liapunov som »Conversations with Bakhtin«, PMLA, vol. 109, nr. 5, oktober 1994, pp. 1009-24.

2. In: B.A. Stolz et al (ed.): Language and Literary Theory, Michigan, 1984, pp. 53564.

3. In: Calin-Andrei Mihailescu \& Walid Hamarneh (ed.): Fiction Updated. Theories of Fictionality, Narratology, and Poetics, Toronto, 1996, pp. 257-66.

4. ['Forgrundende' er en fordanskning af det engelske 'foregrounding' o.a.], og 'foregrounding' er Paul L. Garvins oversættelse af det tjekkiske ord 'aktualisace' i $A$ Prague School Reader on Esthetics, Literary Structure, and Style (Washington, 1964). 'Aktualisace' blev (mener jeg) først anvendt af Jakobson til at bringe hans eget koncept om dominanten sammen med Shklovskijs 'ostranenie'. Hvilken rolle 
det tyske Verfremdung spillede i Mukarovskijs og Jakobsons Prag og tjekkisk ved jeg ikke.

5. Bocharov, p.1010 (se note 1).

6. Michael Holquist: Dialogism: Bakhtin and His World, London, 1990,

7. Gary Saul Morson \& Caryl Emerson: Mikhail Bakhtin. Creation of a Prosaics, Stanford, 1990, p. 436.

8. David K. Danow: The Thought of Mikhail Bakhtin. From Word to Culture, London, 1991.

9. Det professionelle angreb på Bachtin som renæssanceforsker nåede dets ufine kulmination i Richard M. Berrongs Rabelais and Bakhtin: Popular Culture in Gargantua and Pantagruel, Nebraska, 1986. En oversigt er lavet af Mary B. McKinley (indeholder også en anmeldelse af Berrong), »Bakhtin and the World of Rabelais Critism«, Degrè Second: Studies in French Literature, nr. 11, sept. 1987, pp.83-88.

10. F. Burwick \& P. Douglass (ed.): The Crisis in Modernism. Bergson and the Vitalist Controversy, Cambridge, 1992, pp.76-97.

11. =p.cit., p.76.

12. Matejka, p. 262 (se note 3).

13. Morson \& Emerson, p.458 (se note 7).

14. Matejka, p.265-66 (se note 3).

15. op.cit., p.264-65.

16. Bakhtin: Problems of Dostojevsky's Poetics, udgivet og oversat af Caryl Emerson, Minneapolis, 1984, p.299.

17. Se »Note on Translation« i M.M. Bakhtin: Speech Genres and Other Late Essays, oversat af Vern McGee, Austin, 1986, p. vii. Se også Art and Answerability, Austin, 1990, p.235, note 28 .

18. The Dialogic Imagination, Austin, 1981, p.136.

19. Op.cit., p.239. 